\title{
Capital Structure and Firm's Performance of Jordanian Manufacturing Sector
}

\author{
Zeyad Saleem Ramadan $^{1} \& \operatorname{Imad}_{\text {Zeyad Ramadan }}{ }^{1}$ \\ ${ }^{1}$ Department of Finance, Applied Science University, Amman, Jordan \\ Correspondence: Imad Zeyad Ramadan, Associate Prof., Department of Finance, Applied Science University, P.O. \\ Box 166, Amman, Jordan. E-mail: i_ramadan@asu.edu.jo
}

\begin{abstract}
This study aimed to identify the effect of capital structure on the performance of the industrial Jordanian Companies listed on Amman Stock Exchange during the period between: 2005 to 2013, whereas this study was applied on all Jordanian industrial companies listed at ASE and which amount 72 companies as in December, 2013. In order to achieve the objective of the current study the unbalanced cross sectional pooled Ordinary Least Square (OLS) regression model was used. The results of this study showed that there was statistically significant inverse effect of capital structure, expressed by long-term debt to capital ratio, total debt to capital ratio and total debt to total assets ratio, on the performance of the Jordanian industrial companies listed at ASE expressed by Return on asset ratio (ROA), which means that the most profitable companies rely less on borrowing to finance their cash needs, and this result is supported by Pecking-order theory which states that the relationship between borrowing and profitability of the company is an inverse relationship so that the most profitable companies are less dependent on profits to finance their needs.
\end{abstract}

Keywords: capital structure, firm value, Jordan

\section{Introduction}

Capital structure varies between different industrial sectors and companies within the industrial sector, and a study by (Modigliani \& Miller, 1958) was one of the studies on capital structure and its impact on the value of the company. This study has concluded, under the perfect capital market assumption, that the value of the company is not affected by the composition of capital. However, this result is incorrect practically, due to the lack of reality of study's hypotheses (M. \& M., 1958). In the last decade, there were several theories that illustrated capital structure for companies such as Pecking-order theory, The Static-order theory and the agency cost theory. Despite the dialectic of Optimal Capital Structure has not received general acceptance so far, but many studies have supported this idea (Wippen, 1966; Ozkan, 2001).

The Optimal Capital Structure is considered as an outcome of the reciprocal relationship (Trade-off) between the benefits of the tax savings resulting from the use of debt as a source of funding and the risk of bankruptcy resulting from high debt, which is pressing toward the use of property funds to finance the company's needs for funds level. Therefore, the funding decision is considered as one of the most complex decisions taken by the administration, which is represented by the optimal mix of property funds and borrowing money to finance the company's need for funds, which results in a reduction in the cost of capital to a minimum with risks remaining within the acceptable range, which is positively reflected on the market value of the company's shares, which is reflected in the wealth of the owners of the company.

Theoretically, there could be Optimal Capital Structure that works to reduce the overall cost of capital to a minimum. In practice, there are several factors that control the capital structure represented by the risk that the company is ready to bear, the nature of the activity of the company, size of the company, the company's growth rate and other factors that have an impact on the performance of the company, and therefore, the problem of the study lies in the lack of clarity of the impact of capital structure on the value of the company with the need for managers to choose a suitable financing structure for the company that contributes to maximize its value, and thus maximizing the wealth of the owners of the company. Accordingly, the study seeks to answer the following question: Does the capital structure statistically affect the value of the company? 
This study aims to identify the effect of capital structure on the value of the Jordanian industrial companies listed on Amman Stock Exchange (ASE) during the study period from 2005 to 2013. Therefore, the null hypothesis that the study seeks to test is: There is no statistically significant effect of capital structure on the value of the Jordanian industrial companies listed on the Amman Stock Exchange at a significant level 0.05 or less.

\section{Literature Review}

Abdul Jalil (2014) aimed at examining the effect of capital structure on the performance of the Jordanian industrial companies listed at Amman Stock Exchange (ASE). This study has concluded that there were statistically significant inverse relationship between Debt ratio and Return on Investment, and a statistically significant inverse relationship between the Debt to Equity Ratio and Return on Investment. Al Taani (2013) aimed to study the relationship between capital structure and profitability of industrial Jordanian public shareholding companies listed at Amman Stock Exchange (ASE) during the period 2005 to 2009. This study concluded that there were no statistically significant relationship between Debt ratio and Return on assets.

Ramadan and Aloqdeh (2011) aimed at identifying determinants of capital structure of Jordanian industrial companies and found a statistically significant inverse relationship between capital structure and debt ratio and profitability at Jordanian industrial companies. Shlash et al. (2008) aimed at identifying the most important determinants of the financial structure of the Jordanian industrial companies listed in the Amman Stock Exchange, and concluded that there was a statistically significant difference between the financial structure and each of profitability, liquidity and growth rate of the Jordanian industrial companies.

Fozia et al. (2011) aimed at studying the effect of capital structure on the profitability of the Pakistani companies during the period between 2004 to 2009 . This study found a statistically significant inverse relationship between Debt ratio and Return on assets ratio. Prahalathan and Ranjani (2001) aimed at examining the relationship between the capital structure and the performance of Sri-Lankan companies listed on Colombo Stock Exchange during the period between 2003 to 2007. It concluded that there was no statistically significant relationship between Debt ratio and profitability of the Sri Lankan companies.

Matja and Mramor (2006) aimed at identify the factors affecting the capital structure of Slovenian companies, found a statistically significant inverse relationship between debt ratio in the capital structure and each of the tangible assets and the volatility of income and profitability of the company, and a statistically significant positive relationship between debt ratio and each of the company's size and rate of growth of the company. Also, this study has concluded that other factors that have been proposed as determinants of the capital structure were not within the neoclassical theory of capital structure (the power of workers and the owned capital) and was not statistically significant as capital structure determinants in Slovenian companies.

Ong and Heng (2001) investigate the relationship between capital structure and performance of Malaysian construction companies during the period 2005 to 2008. The result suggested significant relationship between capital structure and Malaysian Construction Company's performance. Abor (2005) investigated the effect of the capital structure on the profitability of listed companies on the Ghana Stock. The results suggested a significant positive relationship between short-term debt and the Ghanaian company's profitability, as firms earn more it use more short-term debt to finance their business. Gleason, Mathur, and Mathur (2000) investigated the association between capital structure and performance in 14 European countries; the results show that capital structure significantly affects the performance.

Fama and French study (2002) and Wald (1999), found that profitability was the most important factor in determining the capital structure, where they found a statistically significant inverse relationship between profitability and debt ratio in capital structure. Shyam and Myers (1999), Lemmon and Zender (2004) and Chirinko and Singha (2000) have concluded that the heterogeneous information between managers and investors makes companies to prefer to borrow funds to finance their needs over issuing new shares.

\section{Methodology}

This study utilizes the unbalanced cross sectional pooled Ordinary Least Square (OLS) regression model to investigate the effect of the of capital structure on the Jordanian firms' performance. Dependent and independent variables are pooled cross section time series for estimation.

\subsection{Sample}

This study utilizes the 72 (all) listed manufacturing Companies in Amman Stock Exchange (ASE) during the period of 2005 to 2013. There were 72 unbalanced cross section and 9 time periods, resulting in 629 firm/year observations. 


\subsection{Variables of the Study}

The Financial dataset were obtained from the annual reports of the 72 listed companies available at the official website of ASE.

\subsubsection{Dependent Variable: Firms' Performance (F_P)}

Profitability of the company was used as a proxy for the firms' performance. Profitability of the company is usually expressed by using the company's return on assets (ROA) which is defined as net income before taxes divided by total assets, Calculated as:

$$
R O A=\frac{\text { Net Income }}{\text { Total Assets }}
$$

This scale is considered as the most common scale in the studies that examined the factors affecting the capital structure. The importance of this variable stems from the fact that profitability of the company strongly affects the financial risk faced by the company, where the greater the profitability of the company, the possibility of its failure decreases, and its ability to borrow increases, and thus its ability to achieve tax savings increases, on the one hand, and the greater profitability the company achieves, the company can finance its activities and finance its expansion from its profits, and thus, company's reliance on external sources of funding decreases. So, because companies that achieve large profits have greater capacity to borrow and can make better use of tax savings resulting from the borrowing, the Trade-Off Theory sees a positive relationship between the company's profits and debt ratio in its capital structure, while the Pecking-Order-Theory sees that companies that achieve large profits can benefit from these profits to fund their projects without resorting to external sources of funding, so this theory suggests an inverse relationship between the profitability of the company and debt ratio in its capital structure.

\subsubsection{Independent Variable: Capital Structure}

The expression of the capital structure will be of three variables:

Long term debt to total capital ratio (LD_C), a measurement of a company's financial leverage, calculated as the company's long-term debt divided by its total capital. Total capital includes the company's debt and shareholders' equity, which includes common stock, preferred stock, minority interest and net debt. LD_C can be calculated as:

$$
\text { LD_C }=\frac{\text { Long term Debt }}{\text { Total Capital }}
$$

Total debt to total capital ratio (TD_C), a measurement of a company's financial leverage, calculated as the company's total debt divided by its total capital. Total debt includes all short-term and long-term obligations. Total capital includes the company's debt and shareholders' equity, which includes common stock, preferred stock, minority interest and net debt. TD_C can be calculated as:

$$
\text { TD_C }=\frac{\text { Short term Debt }+ \text { Long term Debt }}{\text { Total Capital }}
$$

Total debt to total assets ratio (TD_A), a leverage ratio that is defined as the total amount of debt to total assets. The higher the ratio is, the higher the leverage, and as a result, financial risk. This is a broad ratio that includes long-term and short-term debt as well as all assets. TD_A can be calculated as:

$$
T D \_A=\frac{\text { Short term Debt }+ \text { Long term Debt }}{\text { Total Assets }}
$$

\subsection{Econometric Model}

This study seeks to investigate the effect of the Jordanian firm's capital structure on its market value by utilizing the unbalanced pooled multiple regression Ordinary Least Square (OLS) estimator framework. The regression model can be written as follows:

$$
F \_P_{i t}=\alpha+\beta_{1} L D \_C_{i t}+\beta_{2} T D_{-} C_{i t}+\beta_{3} T D_{-} A_{i t}+\varepsilon
$$

Where: $F_{-} P_{i t}$ is the firms' performance expressed as the firms' profitability defined as net income to total assets ratio, for the $\mathrm{i}^{\text {th }}$ cross sectional during the $\mathrm{t}^{\text {th }}$ period as $\mathrm{i}=1,2,3, \ldots, 72$ and $\mathrm{t}=1,2,3, \ldots, 9 . \alpha$ is intercept. $\beta^{\prime s}$ are unknown coefficients to be estimated. $L D_{-} C$ is the long-term debt to capital ratio, the first proxy of the capital structure. $T D_{-} C$ is the total debt to capital ratio, the second proxy of the capital structure. $T D_{-} A$ is total debt to total assets ratio, the third proxy of the capital structure. $\varepsilon$ is the error term. 


\section{Empirical Results}

\subsection{Descriptive Analysis}

Table 1 shows the results of the descriptive analysis of the variables of the study.

Table 1. Descriptive analysis

\begin{tabular}{ccccccc}
\hline Variables & N & Min & Max & Mean & Median & STDEV \\
\hline P_F & 629 & -0.193 & 0.382 & 0.037 & 0.042 & 0.138 \\
LD_C & 629 & 0.048 & 3.676 & 0.487 & 0.437 & 0.617 \\
TD_C & 629 & 0.061 & 2.712 & 0.593 & 0.392 & 0.635 \\
TD_A & 629 & 0.025 & 0.831 & 0.327 & 0.294 & 0.193 \\
\hline
\end{tabular}

Note. $P_{-} F$ Firms' performance defined as net income to total assets ratio (ROA), $L D_{-} C$ is the long-term debt to capital ratio. $T D_{-} C$ is the total debt to capital ratio, $T D_{-} A$ is total debt to total assets ratio.

The results of descriptive analysis in Table 1 showed that the performance of the Jordanian industrial companies P_F (study sample), expressed by Return on Assets (ROA) was relatively low, with an average of $3.7 \%$ and a standard deviation of 0.138 .

The table also shows that the Jordanian industrial companies heavily rely on Equity to finance their cash needs where Total debt to assets ratio (TD_A) was about 33\%, suggesting that the Jordanian industrial companies finance their assets by about $67 \%$ of Equity.

The Table also shows that Total Debt to Capital (TD_C) of Jordanian industrial companies has amounted to about $59.3 \%$ and the highest value has amounted $271.2 \%$, while the less value was $6.1 \%$ with a standard deviation of 0.635 .

\subsection{Correlation Analysis}

The results of the correlation analysis in Table 2 show an inverse statistically significant correlation between the capital structure and firms' performance of the Jordanian manufacturing companies.

Table 2. Pearson correlation analysis

\begin{tabular}{cccc}
\hline & LD_C & TD_C & TD_A \\
\hline \multirow{3}{*}{ P_F } & $-0.267^{* *}$ & $-0.301^{* *}$ & $-0.147^{*}$ \\
& 3.042 & 4.92 & 2.03 \\
& 629 & 629 & 629 \\
\hline
\end{tabular}

Note. First line Pearson correlation coefficient, second line t-value, third line number of observations. *** $1 \%$ and $5 \%$ significance level respectively. $P_{-} F$ firms' performance defined as net income to total assets ratio, $L D_{-} C$ is the long-term debt to capital ratio. $T D_{-} C$ is the total debt to capital ratio, $T D \_A$ is total debt to total assets ratio.

The correlation coefficient between the performance proxy (ROA) and the proxies of the capital structure LD_C, TD_C and TD_A were $-0.267,-0.301$ and -0.147 respectively.

\subsection{Regression Analysis}

The regression results of the econometric model (equation 5) are shown in Table 3.

Table 3. Multiple regression analysis of equation 5

\begin{tabular}{llll}
\hline Variable & $\beta$ & t-value & Sig. \\
\hline Constant & 1.071 & 0.919 & 0.358 \\
LD_C & -0.271 & -2.027 & 0.043 \\
TD_C & -0.007 & -3.306 & 0.001 \\
TD_A & -0.845 & -2.090 & 0.037 \\
F-value & & 51.11 & \\
P-value & & 0.000 & \\
$R^{2}$ & & 0.197 & \\
\hline
\end{tabular}




\begin{tabular}{lc}
\hline Adju- $R^{2}$ & 0.193 \\
df Regression & 3 \\
Residual & 625 \\
Total & 628 \\
\hline
\end{tabular}

Note. $L D_{-} C$ is the long-term debt to capital ratio. $T D_{-} C$ is the total debt to capital ratio, $T D_{-} A$ is total debt to total assets ratio.

As shown in Table 3, the result of the multiple-regression analysis shows the F-value to be 51.11 and statistically significant at a 0.000 level. The Adju- $\mathrm{R}^{2}$ shows that the econometric model of the study is able to explain about 0.193 of the variation in the firms' performance expressed as the ratio of the return on the assets. The $\beta$ (regression Coefficient) of the $L D \_C$ has a value of -0.271 and statistically significant at 0.043 level. $T D \_C$ has a negative $\beta$ value of 0.007 and statistically significant at 0.001 level, were $T D_{-} A$ has a negative $\beta$ value of 0.845 and statistically significant at 0.037 level. Based on the regression analysis as shown in Table 3 , the results conclude a statistically significant adverse effect for all proxies of the capital structure on the firms' performance of the Jordanian manufacturing listed companies.

\section{Conclusion}

This study aimed to identify the effect of capital structure on the performance of the industrial Jordanian Companies listed on Amman Stock Exchange during the period between: 2005 to 2013, whereas this study was applied on all Jordanian industrial companies listed at ASE and which amount 72 companies as in December, 2013. In order to achieve the objective of the current study the unbalanced cross sectional pooled Ordinary Least Square (OLS) regression model was used. The results of this study showed that there was statistically significant inverse effect of capital structure, expressed by long-term debt to capital ratio, total debt to capital ratio and total debt to total assets ratio, on the performance of the Jordanian industrial companies listed at ASE expressed by Return on asset ratio (ROA), which means that the most profitable companies rely less on borrowing to finance their cash needs, and this result is supported by Pecking-order theory which states that the relationship between borrowing and profitability of the company is an inverse relationship so that the most profitable companies are less dependent on profits to finance their needs.

\section{Acknowledgements}

The author is grateful to the Applied Science Private University, Amman, Jordan, for the financial support granted to this research project (Grant No. DRGS-2014-2015-142).

\section{References}

Abdul, J. T. (2014). The impact of capital structure on the performance of the Jordanian public shareholding industrial companies. The Journal of Jordan in Business Administration, 12(3).

Abor, J. (2005). Emerald Group Publishing. Journal of Risk Finance, 6(5), 438-445. http://dx.doi.org/10.1108/15265940510633505

Akintoye, I. R. (2008). Sensitivity of Performance to Capital Structure. European Journal of Social Science, $7(1)$.

AL-Taani, K. (2013). The Relationship between Capital Structure and Firm's Performance. Journal of Finance and Accounting, 1(3), 41-45. http://dx.doi.org/10.11648/j.jfa.20130103.11

Chirinko, R., \& Singha, A. (2000). Testing static tradeoff against pecking order models of capital structure: A critical comment. Journal of Financial Economics, 58, 417-425. http://dx.doi.org/10.1016/S0304-405X(00)00078-7

Fama, E. F., \& French, K. R. (2002). Testing tradeoff and pecking order predictions about dividends and debt. The Review of Financial Studies, 15, 1-33. http://dx.doi.org/10.1093/rfs/15.1.1

Fozia, M., Niaz, A. B., \& Ghulam, A. (2011). Capital Structure and Firm Performance: A Case of Textile.

Gleason, K. C., Mathur, L. K., \& Mathur, I. (2000). The Interrelationship between Culture, Capital Structure, and Performance: Evidence from European Retailers. Journal of Business Research, 50(2), 185-191. http://dx.doi.org/10.1016/S0148-2963(99)00031-4

Lemmon, M. L., \& Zender, J. (2004). Debt capacity and test of capital structure. The Journal of Finance, 45 , 1471-1493.

Matja, Č., \& Du.an, M. (2006). Alternative Capital Structure Explanations. Retrieved from 
http://miha.ef.unilj.si/_dokumenti3plus2/196836/11_06APF.pdf

Modigliani, F., \& Miller, M. H. (1958). The cost of capital, corporate finance and the theory of investment. American Economic Review, 48, 261-297.

Ong, S., \& The, H. (2001). Capital Structure and Corporate Performance of Malaysian Construction Sector. International Journal of Humanities and Social Science, 1(2), 28-36.

Oskan, A. (2001). Determinants of capital structure \& Adjustment to long run target: Evidence from UK company panal data. Journal of Business Financial \& Accounting, 28(1\&2), 175-198.

Pratheepkanth, P. (2011). Capital Structure and Financial Performance: Evidence from Selected Business Companies in Colombo Stock Exchange, SriLanka. Journal of Arts, Science and Commerce, 2(2), 171-173.

Ramadan, I., \& Aloqdeh, S. (2011). The Determinants of Capital Structure-Evidence from Jordan. Jordan Journal of Business Administration, 7(2), 228-245.

Sector of Pakistan. (n.d.). Asian Journal of Business and Management Sciences, 1(9), 9-15.

Shlash, S. A. S. B. (2008). Determinants of the financial structure of the business Applied case in Jordanian public shareholding companies listed on the Amman Stock Exchange for the period (1997-2001). Almanarh, 14(1), 45-81.

Shyam-Sunder, L., \& Myers, S. C. (1999). Testing static tradeoff against pecking order models of capital structure. Journal of Financial Economics, 51, 219-244. http://dx.doi.org/10.1016/S0304-405X(98)00051-8

Wald, J. K. (1999). How firm characteristics affect capital structure: An international comparison. Journal of Financial Research, 22, 161-187. http://dx.doi.org/10.1111/j.1475-6803.1999.tb00721.x

\section{Copyrights}

Copyright for this article is retained by the author(s), with first publication rights granted to the journal.

This is an open-access article distributed under the terms and conditions of the Creative Commons Attribution license (http://creativecommons.org/licenses/by/3.0/). 